\title{
Konsep Ekonomi Pada Masa Rasulullah
}

Jika merujuk kedalam alur sejarah, Konsep ekonomi islam memang sudah melalui banyak fase yang sangat lama. Fase Pertama, di kenal dengan "era jahiliyah". Fase Kedua di kenal dengan fase negara agraris pemberi upeti dalam kurung tahun 660-950. Fase Ketiga di kenal dengan era negara perdagangan pemberi upeti dalam kurung waktu 950-1550. Fase Keempat dengan kurung waktu 1550-1850 merupakan masa formasi aktivitas kerajaan pinggiran. serta fase kelima, pada kurung waktu 1850 sampai sekarang di kenal dengan fase kapitalisme pinggiran. (Sirajuddin, 2016)

Awal mula ekonomi Islam bersamaan dengan pertumbuhan tasyri'. Peletakan dasar serta ketentuan perekonomian Islam sudah diawali semenjak era Rosulullah SAW. Dimana Baginda mempraktikkan dasar ekonomi di golongan warga madinah, kala itu perekonomian berbasis Islam sudah diawali. Yang dibentuk diatas dasar Al-Qur' an dengan berlandaskan persaudaraan, persamaan hak, kebebasan serta keadilan. Semacam yang dipaparkan oleh $\mathrm{Sa}^{\prime}$ id $\mathrm{Sa}^{\prime}$ dalam Madkhallil- fikri al- iqtishadiyah fii al- Islam Praktek ekonomi ataupun perdagangan warga Arab dikala itu. tidak hanya mengenal barter, melainkan telah berlaku pula sistem jual beli yang menggunakan mata uang emas Romawi (dinar) dan perak Persia (dirham) sebagai alat transaksi yang efektif. Aktifitas tukar menukar valuta asing, anjak piutang dan pembayaran tidak tunai pun telah dikenal dan dipraktikkan saat itu. Dan dari awal sejarah perkembangan ekonomi Islam, umat muslim telah memiliki sistem yang establish, dengan adanya pelarangan riba dalam pengalokasian sumber daya untuk keperluan produksi maupun konsumsi. Sistem keuangan yang berlaku juga telah menggunakan asas bagi hasil dan kerja sama yang adil. Bahkan perdaganagn dan pinjaman tanpa bunga sudah dipraktikkan dalam transaksi keuangan masyarakat.(Istiqomah et al., 2019)

Sebelum hijrah ke Madinah, Baginda Rasulullah sudah menanamkan nilai-nilai ekonomi Robbani dalam ummatnya walaupun masih sekedah aplikatif. Di Mekkah Masyarakat Muslim sudah di tanamkan ajaran-ajaran seperti larangan Transaksi yang di haramkan. Setelah Hijrah ke Madinah, Barulah Baginda Rasulullah Saw merancang konsep ekonomi secara Universal mulai dari kebijakan Fiskal dan Moneternya. Kehadiran Rasulullah di Madinah dalam waktu singkat membuat Baginda ditunjuk sebagai pemimpin sesuatu komunitas kecil dari para pengikutnya, tetapi jumlah tersebut terus menjadi bertambah. Nyaris seluruh warga Madinah senang dengan 
Nabi Muhammad Saw sebagai pemimpin, tidak terkecuali ummat Yahudi. Di genggaman kepemimpinannya, Madinah tumbuh kilat serta dalam waktu 10 tahun sudah jadi negeri yang besar dibanding dengan daerah lain di segala jazirah Arab. Di Madinah, Baginda Rasul pun mula- mula mendirikan Masjid sebagai tempat majelis, ibadah dan pusat pemerintahan.(Mudhiiah, 2015)

Pemasalahan Kasus-kasus ekonomi yang dibentuk Rasulullah di Madinah dicoba sehabis menuntaskan urusan politik serta permasalahan konstitusional. Baginda Rasul mengajarkan sistem ekonomi serta fiskal negeri yang cocok dengan perintah al- Qur' an. Al- Qur' an sudah mengajarkan dasar ekonomi. Dalam konsep ekonominya, Islam membolehkan kepemilikan individu, Dalam hal mencari nafkah dan umat muslim memiliki kewajiban mencari nafkah halal serta dengan metode yang adil. Baginda Rasulullah juga menyarankan memperoleh nafkah dengan benar yang merupakan lewat perniagaan serta jual beli. Dengan berniagaan Baginda Rasulullah melarang memperoleh harta secara ilegal serta tidak bermoral. Agama Islam tidak mengajarkan perbuatan menimbun harta kekayaan ataupun memperoleh keuntungan atas kesusahan orang lain. Selain itu, ada banyak pula transaksi yang dilarang Islam, misalnya memperoleh dari hasil judi, menimbunan harta kekayaan, penyelundupan, pasar hitam, korupsi, riba serta aktivitas sejenisnya.(Mudhiiah, 2015)

Kerenanya, untuk meninggalkan transaksi yang di haramkam ini, al- Qur'anul karim memberikan pemecahan dengan metode zakat, shodaqah serta sejenisnya. Ini diisyarati dengan diwajibkannya zakat fitrah pada masa kedua hijriyah tiap bulan ramadhan tiba, yang di salurkan kepada fakir dan miskin, budak, amil zakat, muallaf serta lain- lain. Saat sebelum diwajibkannya zakat, pemberian suatu hal kepada yang memerlukan bertabiat suka rela serta belum terdapat peraturan khusus ataupun syarat hukumnya. Peraturan tentang pengeluaran zakat terjadi di tahun ke- 9 Nabi hijrah kala dasar Islam sudah kuat, daerah negera akan berekspansi dengan kilat serta orang akan berlomba lomba masuk Islam. Peraturan yang dibuat Rasulullah dikala itu antara lain pengumpulan zakat, beberapa barang yang harus membayar zakat, batasan Iqtishadia, serta tingkatan persentase zakat buat beberapa barang yang berbeda- beda. Selain Zakat dan Sedekah, pendapatan Negara juga di peroleh dari Kharaj, Jizyah, Kalalah, Ghanimah, Usr, Wakaf .(Mudhiiah, 2015) 


\section{Daftar Pustaka}

Istiqomah, L., Islam, P. E., \& Global, E. (2019). Jurnal Al-Iqtishod Jurnal Al-Iqtishod. AlIqtishod, 1(1), 1-19.

Mudhiiah, K. (2015). Analisis Sejarah Pemikiran Ekonomi Islam Masa Klasik. Iqthishadia, 8(2), $189-210$.

Sirajuddin. (2016). Konsep Pemikiran Ekonomi Islam. Laa Maysir, 3(1), 46-60.

Penulis Ainan Radiyah

Nim 90100118016 